\title{
Coumarin-Based Polymer and Its Silver Nanocomposite as Advanced Antibacterial Agents: Synthetic Path, Kinetics of Polymerization, and Applications
}

\author{
Ambika Srivastava, Vivek Mishra, Pooja Singh, Rajesh Kumar \\ Department of Chemistry, Centre of Advanced Study, Faculty of Science, Banaras Hindu University, \\ Varanasi 221005, Uttar Pradesh, India
}

Received 23 September 2011; accepted 11 February 2012

DOI 10.1002/app.36999

Published online 2 April 2012 in Wiley Online Library (wileyonlinelibrary.com).

\begin{abstract}
A novel polymer bearing coumarin pendants of 4-allyloxy-2H-chromen-2-one (ACO) was synthesized by atom transfer radical polymerization (ATRP) in toluene at $110^{\circ} \mathrm{C}$ using 2-Bromoisobutyryl bromide (BIBB), $\mathrm{Cu}$ (I) $\mathrm{Br}$, and 2,2'-bipyridyl (bpy) as initiator, catalyst, and ligand, respectively. The most appropriate molar concentration ratio of $[\mathrm{ACO}]:[\mathrm{BIBB}]:[\mathrm{Cu}(\mathrm{I}) \mathrm{Br}]:$ [bpy] was found to be $40: 1: 1: 2$ for controlled polymerization. Successful chain extension polymerization of poly (4-allyloxy-2H-chromen-2-one) (PACO) confirms the livingness of the process. The activation energy $\left(E_{a}\right)\left(76.26 \mathrm{~kJ} \mathrm{~mol}^{-1}\right)$ and enthalpy of activation $\left(\Delta H^{\ddagger}\right)\left(73.07 \mathrm{~kJ} \mathrm{~mol}^{-1}\right)$ were in good agreement to each other proving the feasibility of the reaction and negative value of entropy of activation $\left(\Delta S^{\ddagger}\right)$ $\left(-320 \mathrm{~J} \mathrm{~mol}^{-1} \mathrm{~K}^{-1}\right)$ supported the highly restricted movement of reacting species in transition state during poly-
\end{abstract}

merization. Initial polymer decomposition temperature of PACO was found to be $130^{\circ} \mathrm{C}$. SEM analysis revealed that polymer surface is not smooth with pointed rod like shapes. The polymer/Ag nanocomposite was synthesized and examined in view of antibacterial effect against Enterococcus faecalis, Staphylococcus aureus, Escherichia coli, Proteus mirabilis, and Klebsiella pneumonae. PACO and its Ag nanocomposite (PACON) have been found to be active selectively against bacterial pathogen $E$. fecalis with minimum inhibitory concentration of 50 and $32 \mu \mathrm{g} \mathrm{mL}{ }^{-1}$, respectively. (c) 2012 Wiley Periodicals, Inc. J Appl Polym Sci 126: 395407,2012

Key words: ATRP; 4-allyloxy-2H-chromen-2-one; antibacterial activity; nanocomposite

\section{INTRODUCTION}

In the past decades, the development of living/controlled radical polymerization technique has made it possible to produce macromolecules of various architectures with well-defined structure and narrow molar mass dispersion, ${ }^{1}$ which is currently of great academic and industrial interest. ${ }^{2-6}$ Although several controlled radical polymerization methods have been reported by various groups, ${ }^{7-12}$ atom transfer radical polymerization (ATRP) has emerged as one of the most powerful, versatile, simple, and inexpensive living polymerization technique, which was first reported by Matyjaszewski and coworkers ${ }^{13}$ and Sawamoto and coworkers. ${ }^{14}$ The basic mechanism of ATRP involves a reversible switching between two oxidation states of a transition metal complex. Typi-

Additional Supporting Information may be found in the online version of this article.

Correspondence to: R. Kumar (rkr_bhu@yahoo.com).

Contract grant sponsor: CSIR, New Delhi; contract grant number: 01(2362)/10/EMR-II.

Journal of Applied Polymer Science, Vol. 126, 395-407 (2012) (C) 2012 Wiley Periodicals, Inc. cally, the initiating radicals are generated from an alkyl (pseudo) halide in the presence of a transitionmetal complex in its lower oxidation state (e.g., $\mathrm{CuBr} /$ ligand). Due to the radical nature of ATRP, a wide range of functional monomers can be polymerized, yielding polymers with pendant functional groups. Therefore, various functional monomers with controlled molecular weight and low molar mass dispersion ${ }^{15-17}$ such as styrene, ${ }^{18-21}$ methyl methacrylate, ${ }^{19,22-25}$ allyl methylacrylate, ${ }^{26}$ etc. have been polymerized by ATRP.

Generally, allyloxy end functionalized polymers have been prepared since on the allyloxy group further transformations could be done. ${ }^{27}$ ATRP-based coumarin-end-capped polymers using functional initiators have been synthesized, ${ }^{28}$ but most of the work has been done on copolymerization of coumarins $^{29,30}$ because coumarins, if present as pendant group/side chain ${ }^{31-34}$ in the main polymer chain, can induce the property of photochemical transformation, for example, dimerization. ${ }^{35,36}$ Coumarinbased compounds are widely used for the preparation of liquid crystals ${ }^{37-40}$ and fluorescent polymers. ${ }^{41}$ Most of the coumarin-based polymers including side-group and main-chain polymers have been reported by free radical polymerization ${ }^{29,30,32}$ 
and/or other conventional methods. ${ }^{42-46}$ However, some reports discuss RAFT copolymerization of (styrene/coumarin) using difunctional and hexafunctional ruthenium polypyridine reagents. ${ }^{47}$ RAFT agents/ATRP initiators have been used for introducing coumarins at the polymer chain ends but, no work has been done regarding the homopolymerization of allyloxy coumarin via ATRP protocol with the given optimized reaction conditions to get wellorganized architecture of poly coumarins.

Another aspect of coumarins is that they possess a variety of bioactivities including anticoagulant, estrogenic, photosensitizing, antimicrobial, analgesic, hypothermic $^{48,49}$ as well as antibacterial, ${ }^{50}$ antifungal, $^{51,52}$ anticoagulant, anti-inflammatory, ${ }^{53}$ antitumor, ${ }^{54,55}$ and anti-HIV ${ }^{56}$ activities, which could be used in coumarin-based polymers. The polymeric antimicrobial agents have the advantage that they are nonvolatile, chemically stable, and do not permeate through skin. Thus, they can reduce losses associated with volatilization, photolytic decomposition, and transportation. The polymer/metal nanocomposites are even more effective due to their unique physical and chemical properties compared with their bulk counter parts. ${ }^{57}$ Compounding Ag nanoparticles (AgNPs) with polymer could not only improve their dispersability but also provide with/ or enhance the antimicrobial properties of polymeric materials.

Since no reports are available regarding the homopolymerization of 4-allyloxy coumarin through ATRP thus, keeping in mind the wide application of poly coumarins we have synthesized coumarinbased homopolymer (PACO) via ATRP to get well defined structure of polycoumarins with narrow molar-mass dispersion. Moreover its Ag nanocomposite (PACON) has also been prepared, the idea was to incorporate AgNPs, to attribute into the polymer matrix and disperse them at the nanoscale to observe the effect of polymer and its $\mathrm{Ag}$ nanocomposite on various human bacterial pathogens and to analyze improvements/specialty developed in biological properties.

Thus, in this communication, monomer, polymer and polymer/Ag nanocomposite syntheses, characterization, and optimization of reaction conditions in details, is being reported. The formation of polymer has been established with the help of ${ }^{1} \mathrm{H}-\mathrm{NMR}$ and FTIR spectral data. Gel permeation chromatography was employed to determine the molecular weight of the synthesized polymer. Formation of polymer/Ag nanocomposite was established with the help of UV-visible spectra and Transmission Electron Microscope (TEM) micrograph. The effect of polymer and its Ag nanocomposite on five different human bacterial pathogens has been tested.

\section{EXPERIMENTAL SECTION}

\section{Materials}

All reactions were carried out under purified nitrogen gas. $\mathrm{Cu}$ (I) Br (Aldrich 98\%) was purified by successive washings with glacial acetic acid to remove residual $\mathrm{CuBr}_{2}{ }^{58}$ filtered, washed with absolute ethanol and diethyl ether, dried under vacuum, and stored under purified nitrogen atmosphere. Toluene (AR grade, Merck, India) was dried and purified as per the methods outlined by Perrin and Armarego. ${ }^{59} 2,2^{\prime}-$ Bipyridyl (bpy) (Aldrich, 99\%), 2-bromoisobutyrylbromide (Aldrich, 98\%) and 4-hydroxy coumarin ${ }^{60}$ (Himedia, 99\%), silver nitrate GR (Merck), and sodium borohydride (Merck), were used without further purification. Sodium hydride (Himedia, 55-60\% suspension in mineral oil) was used after washing with hexane.

\section{Methods for calculation of parameters}

integral per proton

$$
=\frac{\text { sum of vinyl proton integrals }}{\text { sum of protons in the two vinyl end groups }}
$$

$$
\text { Number of repeating monomer units }(\mathrm{n})=\frac{\text { sum of methylene proton integrals/sum of methylene protons }}{\text { integral per proton }}
$$

\section{$\left(M_{n}\right)$ :}

$\mathrm{Mn}_{\mathrm{NMR}}=(\mathrm{MW}$ end group $)+(\mathrm{MW}$ repeatingunit $)$

$$
\times(n)
$$

where $M_{W}$ end group = molecular weight of end group, $M_{W}$ repeating units = molecular weight of repeating units, $n=$ Number of repeating monomer units. The $M_{n \mathrm{NMR}}$ of polymers can be calculated using eqs. (1)-(3).

Calculation of Conversion: The conversion of monomer to polymer has been determined by ${ }^{1} \mathrm{H}$ NMR using the eq. (4);

$$
\% \text { Conversion }_{\mathrm{NMR}}=\frac{\mathrm{I}_{\text {Polymer }}}{\mathrm{I}_{\text {Polymer }}+\mathrm{I}_{\text {Monomer }}} \times 100
$$


where $I_{\text {Polymer }}=$ peak area (integration) of repeating units of polymer, $I_{\text {Monomer }}=$ peak area (integration) of allylic group of monomer.

All the monomer conversions for the kinetic study have been estimated by ${ }^{1} \mathrm{H}-\mathrm{NMR}$ with the samples directly withdrawn at different time intervals, the monomer conversion being estimated by comparing the peak areas of the monomer and polymer.

$$
\begin{aligned}
& \mathrm{DP}_{n}=\frac{[\text { Monomer }]_{0}}{[\text { Initiator }]_{0}} \times \% \text { Conversion } \\
& \mathrm{NMR} \\
& \mathrm{Mn}_{(\text {Theo })}=\mathrm{DP}_{n} \times M_{\text {Monomer }}+M_{\text {Initiator }}
\end{aligned}
$$

where $[\text { Monomer }]_{0}=$ initial concentration of the monomer, $[\text { Initiator }]_{0}=$ initial concentration of initiator, $M_{\text {Monomer }}=$ molecular weight of monomer, $M_{\text {initiator }}=$ molecular weight of initiator.

$$
\text { Initiator efficiency }(f)=M_{n(\text { Theo })} / M_{n(\mathrm{GPC})}
$$

where $M_{\mathrm{n}(\text { Theo })}=$ number average molecular weight of polymer calculated theoretically, $M_{\mathrm{n}(\mathrm{GPC})}=$ number average molecular weight of polymer obtained by GPC.

It is a well-known fact that by raising the temperature, reaction rate increases, although, quantitatively, activation energy, and frequency factor are determined by the Arrhenius eq. (8):

$$
k=A \cdot e^{-\frac{E_{a}}{R T}}
$$

where $E_{\mathrm{a}}=$ activation energy, $R=8.314\left(\mathrm{~J} \mathrm{~mol}^{-1}\right.$ $\mathrm{K}^{-1}$ ), $\mathrm{T}=$ absolute temperature in $\mathrm{K}, A=$ frequency factor, $A=p \cdot Z$, where $Z$ is the collision rate, and $p$ is a steric factor. $Z$ turns out to be only weakly dependant on temperature. Thus, the frequency factor is a constant, specific for each reaction.

The Eyring equation is calculated from eq. (9). The linear form of the Eyring equation is

$$
\ln \frac{k}{T}=-\frac{\Delta H^{\ddagger}}{R T}+\ln \frac{k_{B}}{h}+\frac{\Delta S^{\ddagger}}{R}
$$

where $k_{\mathrm{B}}=$ Boltzmann's constant $\left(1.381 \times 10^{-23} \mathrm{~J}\right.$ $\left.\mathrm{K}^{-1}\right), T=$ absolute temperature in $\mathrm{K}, h=$ Plank constant $\left(6.626 \times 10^{-34} \mathrm{~J} \mathrm{~s}\right), k=$ reaction rate constant.

A plot of $\ln (k / T)$ versus $1 / T$ produces a straightline then, $y=-m x+b$, where $(x=1 / T)$. Enthalpy of activation $\left(\Delta H^{\ddagger}\right)$ can be calculated from the slope $m$ of this line: $\Delta H^{\ddagger}=-m R$.

From the $y$-intercept

$$
y(x=0)=\ln \frac{k_{B}}{h}+\frac{\Delta S^{\ddagger}}{R}
$$

Entropy of activation $\left(\Delta S^{\ddagger}\right)$ can be determined and thus the calculation of $\Delta G^{\ddagger}$ for the appropriate reaction temperatures according to eq. (11) is allowed.

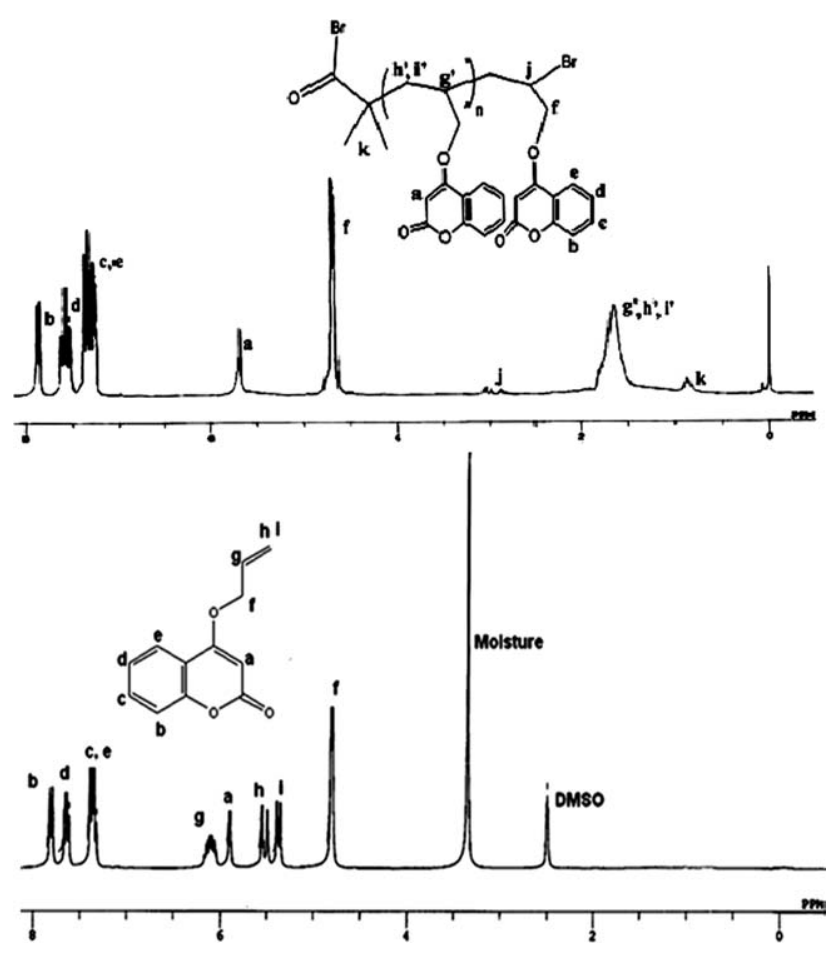

Figure $1{ }^{1} \mathrm{H}-\mathrm{NMR}$ spectra of ACO in DMSO- $d_{6}$ and $\mathrm{PACO}$ in $\mathrm{CDCl}_{3}$ showing positions of protons.

$$
\Delta G^{\ddagger}=\Delta H^{\ddagger}-T \cdot \Delta S^{\ddagger}
$$

where $R=$ Universal gas constant $=8.3145\left(\mathrm{~J} \mathrm{~mol}^{-1}\right.$ $\left.\mathrm{K}^{-1}\right), \Delta G^{\ddagger}=$ Gibbs free energy of activation $(\mathrm{kJ}$ $\left.\mathrm{mol}^{-1}\right), \Delta S^{\ddagger}=$ Entropy of activation $\left(\mathrm{J} \mathrm{mol}^{-1} \mathrm{~K}^{-1}\right)$, $\Delta H^{\ddagger}=$ Enthalpy of activation $\left(\mathrm{kJ} \mathrm{mol}^{-1}\right)$.

\section{Monomer synthesis and characterization data}

To a solution of 4-hydroxy coumarin (HC) $(10 \mathrm{mmol}$; $1620 \mathrm{mg})$ in dry DMF $(10 \mathrm{~mL})$ in ice-bath was added $\mathrm{NaH}(20 \mathrm{mmol} ; 460 \mathrm{mg})$ in completely anhydrous conditions and stirred for $30 \mathrm{~min}$ followed by the addition of allyl bromide ( $20 \mathrm{mmol} ; 2 \mathrm{~mL}$ ) and stirred at room temperature until the reaction was complete, as monitored by TLC. The solvent was evaporated and the reaction mixture was quenched with water to remove water-soluble impurities followed by extraction with ethyl acetate. Further, the organic extract was evaporated to yield the crude solid product. The solid was chromatographed with ethyl acetate-hexane to obtain the pure product. White crystalline solid was obtained. Yield: $80 \%$, m.p. $103^{\circ} \mathrm{C} .{ }^{1} \mathrm{H}-\mathrm{NMR}\left(300 \mathrm{MHz}\right.$, DMSO- $\left.d_{6}\right)$ $\delta 4.81\left(\mathrm{~d}, 2 \mathrm{H}, \mathrm{H}^{\mathrm{f}}\right), 5.39\left(\mathrm{~d}, 1 \mathrm{H}, J=10.8 \mathrm{~Hz}, \mathrm{H}^{\mathrm{i}}\right), 5.54(\mathrm{t}$, $\left.1 \mathrm{H}, J=16.2 \mathrm{~Hz}, \mathrm{H}^{\mathrm{h}}\right), 5.902$ (s. $\left.1 \mathrm{H}, \mathrm{H}^{\mathrm{a}}\right), 6.108(\mathrm{~m}, 1 \mathrm{H}, J$ $\left.=27.9 \mathrm{~Hz}, \mathrm{H}^{\mathrm{g}}\right), 7.339\left(\mathrm{~d}, 1 \mathrm{H}, J=7.5 \mathrm{~Hz}, \mathrm{H}^{\mathrm{e}}\right), 7.384(\mathrm{~d}$, $\left.1 \mathrm{H}, J=7.8 \mathrm{~Hz}, \mathrm{H}^{\mathrm{c}}\right), 7.647\left(\mathrm{t}, 1 \mathrm{H}, J=8.4 \mathrm{~Hz}, \mathrm{H}^{\mathrm{d}}\right)$, $7.813\left(\mathrm{~d}, 1 \mathrm{H}, J=7.8 \mathrm{~Hz}, \mathrm{H}^{\text {b }}\right.$; Fig. 1$)$; FTIR $\left(\mathrm{KBr}, \mathrm{cm}^{-1}\right)$ : 3080 (heteroaromatic $-\mathrm{C}-\mathrm{H}$ str), $1722(\mathrm{C}=\mathrm{O}$ str), 1624 (allylic $-\mathrm{C}=\mathrm{C}$ stretching), 1566, 1493, 1443, and 1400 

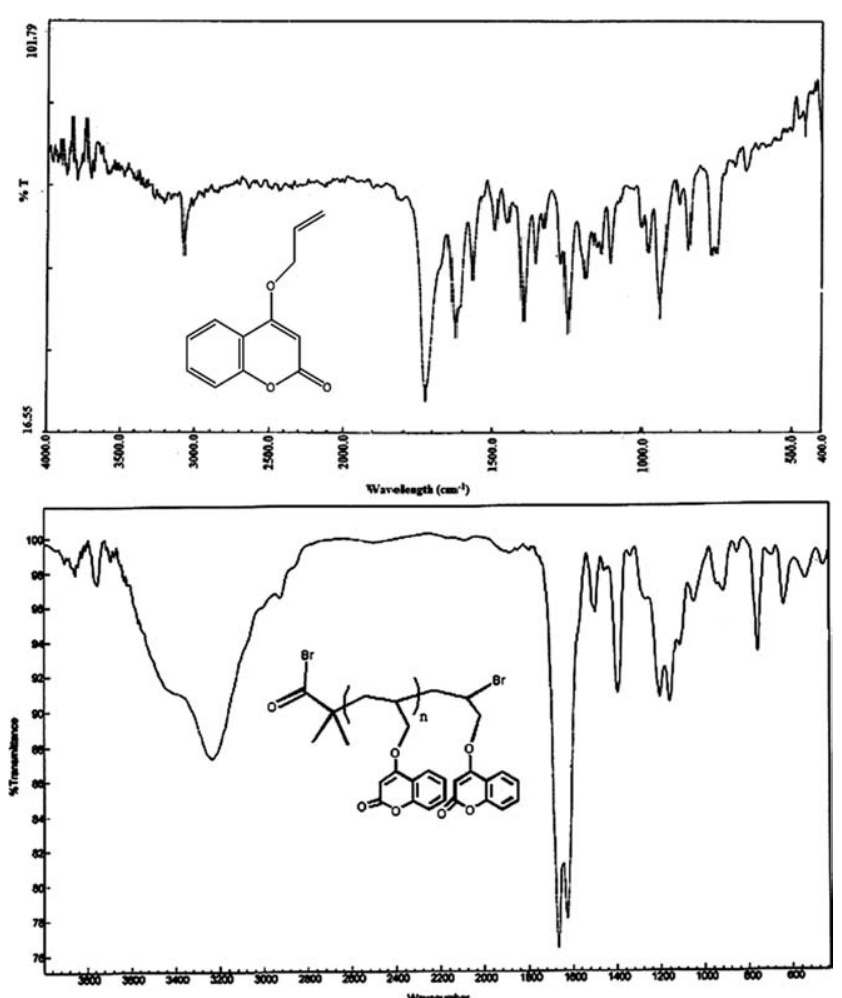

Figure 2 FTIR spectra of ACO and PACO in $\mathrm{KBr}$.

(aromatic C $=$ C str), 1248(-C-O asym str), 939(-C-O sym str) (Fig. 2), m/z: 203 (Supporting Information Fig. S1); UV-vis 212, 275, and 304 nm (Fig. 3).

\section{Crystal structure description of}

\section{4-allyloxy-2H-chromen-2-one (ACO) monomer}

The PLATON draw of monomer together with the atom-numbering scheme has been shown in Figure 4 . The various crystallographic parameters

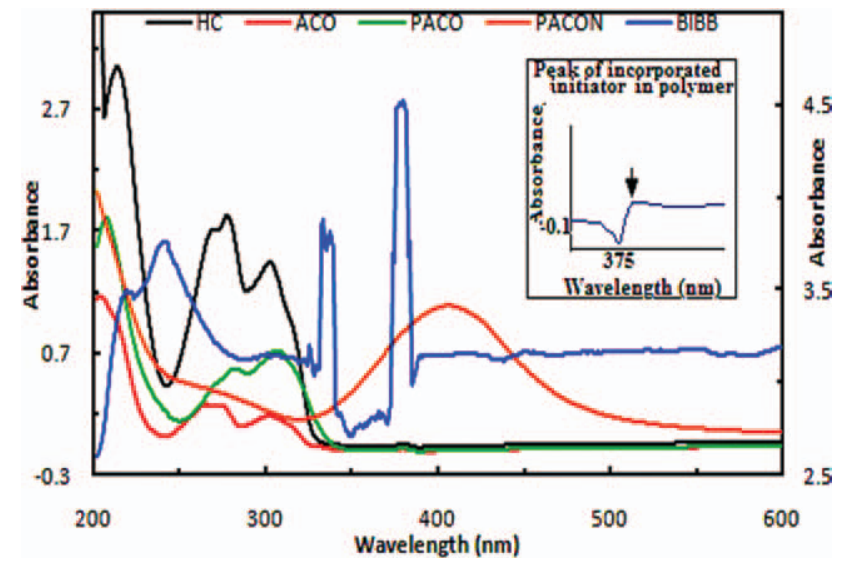

Figure 3 UV spectra of $\mathrm{HC}, \mathrm{ACO}, \mathrm{PACO}, \mathrm{PACON}$, and BIBB (In Inset: Incorporated initiator in the polymer). $\varepsilon_{\max }$ $=2.8 \times 104$ for the initiator. [Color figure can be viewed in the online issue, which is available at wileyonlinelibrary. com.] have been given in Supporting Information Table S1. The bond length between vinyl carbons $\mathrm{C} 022$ and C028 is 1.299(4) $\AA$; allylic carbon C026 and oxygen O6 of coumarin is 1.452(4) $\AA$; C13 and carbonyl oxygen $\mathrm{O} 5$ is $1.216(4) \AA$. The bond angles between vinyl hydrogens and carbon $\mathrm{H} 16 \mathrm{~B}-\mathrm{C} 028-\mathrm{H} 16 \mathrm{~A}$ is 119.9(4) $)^{\circ}$; angle between $\mathrm{O} 4-\mathrm{C} 13-\mathrm{C} 14$ is $118.2(3)^{\circ}$; $\mathrm{C} 15-\mathrm{O} 6-\mathrm{C} 026$ is $117.5(2)^{\circ}$ (Supporting Information Table S2). Crystal structure shows that the two coumarin units are oriented opposite to each other. Coumarin monomer is planar with vinylic group extending out of the plane of the molecule. The oxygen of coumarin ring shows hydrogen bonding with hydrogens of other unit of coumarin. H-bonding in the crystal lattice has been shown with crystal packing where the carbonyl oxygen and ring hydrogens participate in H-bonding (Supporting Information Fig. S2). Mass of the synthesized monomer was determined by mass spectra (Supporting Information Fig. S1) where the molecular ion peak $(m+1)$ appeared at 203, which also confirms the formation of monomer.

\section{Polymer synthesis and characterization data}

Bpy $(0.10 \mathrm{mmol} ; 16 \mathrm{mg})$ and dry toluene $(20 \mathrm{~mL})$ were placed in a three neck round bottomed flask. Three freeze pump thaw cycles were performed to remove any traces of dissolved air or oxygen. Deoxygenated ACO (2 mmol; $404 \mathrm{mg}$ ) and $\mathrm{Cu}$ (I) $\mathrm{Br}$ $(0.05 \mathrm{mmol} ; 6 \mathrm{mg})$ were added and freeze pump thaw cycle was performed. Finally, the flask was purged with nitrogen gas and placed in an oil bath at $110^{\circ} \mathrm{C}$ followed by the addition of deoxygenated 2-Bromoisobutyryl bromide (BIBB; $0.05 \mathrm{mmol}, 0.01$ $\mathrm{mL}$ ) via a degassed syringe. After the desired time, polymerization was quenched by freezing the reaction mixture using liquid nitrogen. Solvent was removed under reduced pressure and the residue

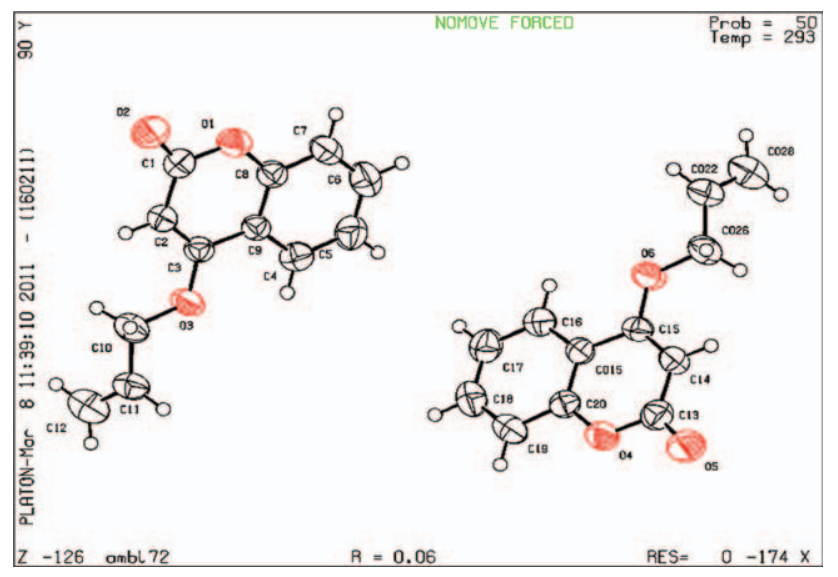

Figure 4 PLATON draw of ACO. [Color figure can be viewed in the online issue, which is available at wileyonlinelibrary.com.] 
was dissolved in THF. Copper catalyst was removed by passing the reaction mixture through a column of basic alumina and the filtrate was then concentrated, followed by dropping into a large amount of $\mathrm{CHCl}_{3}$ and collected by centrifugation, purification was carried out by repeating dissolution in minimum amount of THF and precipitation in $\mathrm{CHCl}_{3}$, and finally dried under vacuum at $60^{\circ} \mathrm{C}$ for $12 \mathrm{~h}$. Pinkish white solid obtained whose monomer conversion was measured by ${ }^{1} \mathrm{H}-\mathrm{NMR}$. Yield: $350 \mathrm{mg},{ }^{1} \mathrm{H}-\mathrm{NMR}$ $\left(300 \mathrm{MHz}, \mathrm{CDCl}_{3}\right) \delta 0.9\left(\mathrm{~s}, 6 \mathrm{H},-2 \mathrm{CH}_{3}^{\mathrm{k}}\right), 1.6(\mathrm{~b}$, $\left.60 \mathrm{H}, \mathrm{H}^{\mathrm{g} \prime}, \mathrm{H}^{\mathrm{h} \prime}, \mathrm{H}^{\mathrm{i} \prime}\right), 3.0\left(\mathrm{~m}, 1 \mathrm{H}, \mathrm{H}^{\mathrm{j}}\right), 4.76\left(\mathrm{~b}, 40 \mathrm{H}, \mathrm{H}^{\mathrm{f}}\right)$, $5.78\left(\mathrm{~b}, 20 \mathrm{H}, \mathrm{H}^{\mathrm{a}}\right), 7.36\left(\mathrm{~b}, 40 \mathrm{H}, \mathrm{H}^{\mathrm{c}}, \mathrm{H}^{\mathrm{e}}\right), 7.59(\mathrm{~b}$, $\left.20 \mathrm{H}, \mathrm{H}^{\mathrm{d}}\right), 7.82\left(\mathrm{~b}, 20 \mathrm{H}, \mathrm{H}^{\mathrm{b}}\right.$; Figs. 1 and Supporting

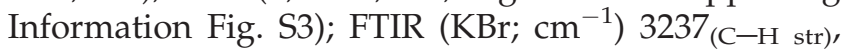

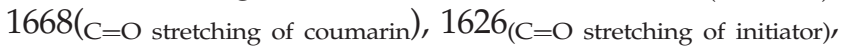
$1497,1393_{\text {(aromatic C=C str) }} 1204_{(\mathrm{C}-\mathrm{O} \text { asym str) }}, 914_{(\mathrm{C}-\mathrm{O} \text { sym str) }}$ 810 ( $-C_{\mathrm{C}}$ stretching), $758_{(-\mathrm{CH} 2 \text { rocking) }} 539_{(\mathrm{C}-\mathrm{Br} \text { stretching) }}$ (Fig. 2); UV-vis 206, 282, and 304 nm (Fig. 3).

\section{Chain extension polymerization using PACO as macroinitiator}

A dry round bottomed flask was charged with purified $\mathrm{CuBr}(0.25 \mathrm{mmol} ; 30 \mathrm{mg})$, bpy $(0.5 \mathrm{mmol} ; 80 \mathrm{mg})$, and dry toluene $(20 \mathrm{~mL})$. The flask was sealed with a rubber septum and cycled between vacuum and nitrogen three times to remove the oxygen. After the $\mathrm{CuBr}$ and bpy were dissolved completely, degassed monomer ACO (5 mmol; $1010 \mathrm{mg})$, and PACO (0.13 mmol; $127.24 \mathrm{mg})$ as macroinitiator $\left(M_{n \mathrm{GPC}}=7526, \mathrm{Ð}_{m}=\right.$ 1.30) were added. The flask was immersed in an oil bath held by a thermostat at $110^{\circ} \mathrm{C}$. The solution was maintained at this temperature for $22 \mathrm{~h}$. Polymerization was terminated by freezing the reaction mixture using liquid nitrogen. Solvent was removed under reduced pressure and the residue was dissolved in THF. The polymer was purified by passing the reaction mixture over a basic alumina column to remove ATRP catalyst/ligand complex and the filtrate was evaporated under reduced pressure. The polymeric residue was redissolved in THF and precipitated in excess chloroform. Filtered, washed with chloroform, and dried under vacuum at $60^{\circ} \mathrm{C}$ for $10 \mathrm{~h}$. The $M_{n}$ and molar mass dispersion of the obtained polymer were determined by GPC.

\section{Synthesis of silver nanoparticles}

Aqueous $\mathrm{AgNO}_{3}(0.1 \mathrm{M} ; 2 \mathrm{~mL})$ was added drop wise (=1 drop s$\left.{ }^{-1}\right)$ to aq. $\mathrm{NaBH}_{4}(0.2 \mathrm{M} ; 30 \mathrm{~mL})$ that has been chilled in an ice-bath. The reaction mixture was stirred vigorously on a magnetic stir plate. The solution turned dark yellow when all of the $\mathrm{AgNO}_{3}$ has been added, indicating the presence of AgNPs in the colloid form due to larger amount of reduction of $\mathrm{AgNO}_{3}$ to AgNPs. The stirring was stopped as soon as the addition was over to prevent agglomeration of AgNPs. A layer of absorbed borohydride anions on the surface of the nanoparticles keep the nanoparticles separated.

\section{Synthesis of polymer/Ag nanocomposite and methods for antibacterial studies}

First, $10 \mathrm{mg}$ of PACO was dissolved in $1 \mathrm{~mL}$ THF to make solution of $1 \mathrm{wt} \%$. The solution of PACO in THF was exposed to ultrasonic bath while addition of $1 \mathrm{~mL}$ of nanosilver solution $(0.1 \mathrm{M})$ drop wise and the solution was further sonicated vigorously for $30 \mathrm{~min}$, at $50^{\circ} \mathrm{C}$. After sonication, THF was evaporated under reduced pressure and the polymer/Ag nanocomposite was precipitated in chloroform as brown powder, which was washed with THF to remove any free PACO, finally, dried in vacuum oven at $60^{\circ} \mathrm{C}$ for $8 \mathrm{~h}$ and further identified as polymer/Ag nanocomposite by TEM micrograph and UV-visible analysis. Antibacterial activity of polymer and its Ag nanocomposite was observed against five clinical isolates of human pathogenic bacteria, that is, Enterococcus faecalis (ATCC25923), Staphylococcus aureus (IMS/GN7), Escherichia coli (ATCC25922), Proteus mirabilis (IMS/Gn13), and Klebsiella pneumonae (IMS/GN9), obtained from IMS BHU, using disc diffusion method. ${ }^{61}$ To each sterile air-dried paper disc, $0.5 \mathrm{mg}$ compound dissolved in methanol was impregnated. The test bacterial culture was spread evenly with cotton swab on the surface of solidified Mueller-Hinton agar Petri plates. The paper discs containing $0.5 \mathrm{mg}$ compound were placed on the surface of the Mueller-Hinton medium seeded with test bacterium in Petri plate. The paper disc dried after impregnating with only methanol of same volume was considered as positive control. Minimum inhibitory concentration (MIC) was also determined against the five bacterial pathogens, that is, Enterococcus fecalis (ATCC25923), Staphylococcus aureus (IMS/GN7), Escherichia coli (ATCC25922), Proteus mirabilis (IMS/Gn13), and Klebsiella pneumonae (IMS/ GN9) using broth dilution method. ${ }^{62}$ Test solution was prepared by diluting the polymer/Ag nanocomposite to known concentration range $\left(2-50 \mu \mathrm{g} \mathrm{mL}^{-1}\right)$ in $2 \mathrm{~mL}$ tubes and $5 \mu \mathrm{L}$ of 1 day old test pathogen culture containing $10^{6}-10^{8}$ cells were added to make $1 \mathrm{~mL}$ final volume of brain heart infusion broth and incubated at $37 \pm 2^{\circ} \mathrm{C}$ for 1 day. Tubes were examined for visible signs of bacterial growth. The lowest concentration of the polymer/Ag nanocomposite, which checks the complete bacterial growth is considered to be the MIC.

\section{Techniques for characterization of monomer, polymer, and silver nanocomposite}

${ }^{1} \mathrm{H}-\mathrm{NMR}$ spectra were recorded at $300 \mathrm{MHz}$ resonance frequency in a JEOL AL300 FT NMR at $25^{\circ} \mathrm{C}$ 
in $\mathrm{DMSO}-\mathrm{d}_{6}$ and $\mathrm{CDCl}_{3}$ using tetramethylsilane as an internal reference. FTIR spectra were recorded on a Varian Excalibur 3000(Palo Alto, CA) spectrophotometer in the region $4000-400 \mathrm{~cm}^{-1}$ on $\mathrm{KBr}$ disc. The electronic absorption spectra were recorded on Perkin Elmer-Lambda 35 UV-vis Spectrophotometer connected with PTP-1 Peltier system at $25^{\circ} \mathrm{C}$. The optical path length of measurement cell was $10 \mathrm{~mm}$. Molecular weight was determined by mass spectrometry using JEOL SX-102 (ESI) instrument. Average molecular weights $\left(M_{w}\right.$ and $\left.M_{n}\right)$ and molar mass dispersion $\left(\bigoplus_{m}\right)$ of all the polymer samples were recorded at $40^{\circ} \mathrm{C}$ on polymer laboratories PL GPC220 with THF as eluent, at a flow rate of $1.0 \mathrm{~mL}$ $\min ^{-1}$. Molecular weights were calculated using monodisperse polystyrene standard. Before injection into the GPC system, the polymer solutions were treated with cation-exchange resin Dowex 50W (Fluka) to free them from Cu salts. Differential Scanning calorimetric analysis of the polymer was carried out on a Make/Model Mettler Toledo DSC 822e apparatus at a heating rate of $10^{\circ} \mathrm{C} \mathrm{min}^{-1}$ from -100 to $350^{\circ} \mathrm{C}$. Differential thermal analysis was carried out on a Make/Model Perkin Elmer, Diamond TG/ DTA instrument with a heating rate of $10^{\circ} \mathrm{C} \mathrm{min}-1$ in the nitrogen flow $80 \mathrm{~mL} \mathrm{~min}^{-1}$. Scanning electron microscopy (SEM) observations were conducted on a JSM-6390 instrument at an accelerating voltage of $25 \mathrm{kV}$. Transmission electron micrograph was taken with Technai FEI TEM operated at $120 \mathrm{kV}$ accelerating voltage. Sonication of polymer/Ag nanocomposite was done by Ultrasonic bath model no. FS30D, make Branson Ultrasonic and marketed by Fisher Scientific, India, operating frequency $25 \mathrm{kHz}$ at $50^{\circ} \mathrm{C}$. Crystal structure determination and refinement data for the structure of ACO was obtained at 293 K (2) on Oxford Diffraction Gemini diffractometer equipped with CrysAlis Pro., using a graphite monochromatic Mo $\mathrm{K} \alpha(k=0.71073 \mathrm{~A})$ radiation source. The structure was solved by direct method (SHELXL-2008) and refined against all data by full matrix least squares on $F^{2}$ using anisotropic displacement parameters for all nonhydrogen atoms. All the hydrogen atoms were included in the refinement at geometrically ideal positions and refined with a riding model. ${ }^{63}$ The MERCURY package and ORTEP-3 programs were used for generating molecular structures. ${ }^{64-66}$

\section{RESULTS AND DISCUSSION}

\section{${ }^{1} \mathrm{H}-\mathrm{NMR}$ and FTIR description of ACO monomer}

From Figure 1, it can be seen that aromatic protons (b, c, d, and e) appear in the range $\delta$ 7.813-7.339 ppm whereas the allylic protons $(\mathrm{g}, \mathrm{h}$, and $\mathrm{i})$ appear at $\delta 6.108,5.54$, and $5.39 \mathrm{ppm}$, respectively. Alkenic proton (a) and methylene proton (f) appeared at $\delta$ 5.902 and $4.81 \mathrm{ppm}$, respectively. From Figure 2, it has been observed that heteroaromatic $-\mathrm{C}-\mathrm{H}$ stretching occurs at $3080 \mathrm{~cm}^{-1}$ whereas the $\mathrm{C}=\mathrm{O}$ stretching being observed at $1722 \mathrm{~cm}^{-1}$. Aromatic $\mathrm{C}=\mathrm{C}$ stretching and alkenic $\mathrm{C}=\mathrm{C}$ stretching being observed at 1566, 1493,1443,1400, and $1624 \mathrm{~cm}^{-1}$, respectively. At $1248 \mathrm{~cm}^{-1}$ asymmetric $-\mathrm{C}-\mathrm{O}$ stretching is observed whereas at $939 \mathrm{~cm}^{-1}-\mathrm{C}-\mathrm{O}$ symmetric stretching has been observed.

\section{Comparative NMR and FTIR analysis of monomer and polymer}

Comparing the ${ }^{1} \mathrm{H}-\mathrm{NMR}$ of the monomer (ACO) and polymer PACO (Fig. 1), it is clear that NMR signals corresponding to the protons $\mathrm{g}, \mathrm{h}$, and $\mathrm{i}$, in monomer have disappeared in the polymer and a new broad signal was seen up field at $\delta 1.6 \mathrm{ppm}$ for the $\mathrm{g}^{\prime}, \mathrm{h}^{\prime}$ and $\mathrm{i}^{\prime}$ protons. Rest of the protons $\mathrm{a}, \mathrm{b}, \mathrm{c} \& \mathrm{e}$, $\mathrm{d}$ and $\mathrm{f}$ appeared at their desired positions, that is, at $\delta 5.78,7.82,7.36,7.59$, and $4.76 \mathrm{ppm}$, respectively, with a very little change in chemical shifts which might be due to the change of different solvents for characterization of ${ }^{1} \mathrm{H}-\mathrm{NMR}$ spectra of monomer and polymer. According to the mechanism of ATRP, initiator is incorporated at $\alpha$-end of the polymer chain, while $\omega$-end remains a terminal halide. It can be verified by ${ }^{1} \mathrm{H}-\mathrm{NMR}$ spectrum that the peak for the methyl protons $(\mathrm{k})$ of initiator appears at $\delta 0.9$ $\mathrm{ppm}$, indicating the incorporation of initiator within the polymer whereas the $j$ proton appears at $\delta 3.0$ ppm. In the FTIR spectra of the polymer (Fig. 2), $\mathrm{C}-\mathrm{H}$ stretching shifted to higher wave number, ${ }^{67}$ that is, $3237 \mathrm{~cm}^{-1}$. This might be due to the presence of halogenated alkyl group present at the chain end of the polymer and a new peak for the halide group at $539 \mathrm{~cm}^{-1}$ was observed. A Fermi resonance type phenomenon was seen in the FTIR spectra of polymer where two peaks resolved by $42 \mathrm{~cm}^{-1}$ were observed at 1626 and $1668 \mathrm{~cm}^{-1}$. It may be due to the presence of two carbonyl groups, one of coumarin and the other of the incorporated initiator or it might be due to the energy of an overtone of the fundamental $\mathrm{C}-\mathrm{C}$ weak stretching vibration at 810 $\mathrm{cm}^{-1}$ that coincided with the fundamental band occurring at $1670 \mathrm{~cm}^{-1}$. Mixing of the two bands ${ }^{67}$ (fundamental and overtone) in accordance with Fermi Resonance gave two bands of almost equal intensity at 1668 and $1626 \mathrm{~cm}^{-1}$.

\section{UV-visible analysis}

The UV-visible spectra of HC, ACO, PACO, PACON, and BIBB have been recorded in methanol. Spectrum of HC and ACO showed peaks at 212, 275, and $304 \mathrm{~nm}$ (Fig. 3). The latter two absorptions 


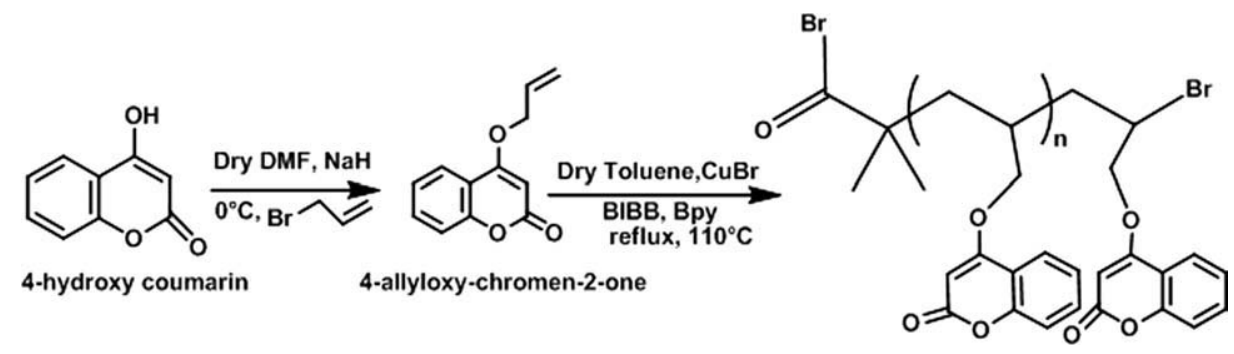

Scheme 1 Synthetic pathway to monomer synthesis and ATRP of 4-allyloxy coumarin with BIBB as initiator in toluene at $110^{\circ} \mathrm{C}$ using $\mathrm{CuBr}$ as catalyst

were assigned to $\pi-\pi^{*}$ and $n-\pi^{*}$ transitions of carbonyl group of coumarin ring and the former was due to $\pi-\pi^{*}$ transitions of allylic bond. Spectrum of the HC was similar to ACO which meant that the allyl group had little/no influence on the absorption spectrum of coumarin ring because the allylic group has no resonance effect with the coumarin unit. The peak at $385 \mathrm{~nm}$ in the polymer spectrum has been assigned for the incorporated initiator in the polymer (Fig. 3, inset). This confirmed the successful ATRP polymerization of ACO. PACO exhibited three absorption maxima at 206, 282, and $304 \mathrm{~nm}$. The latter two absorptions were assigned to $\pi-\pi^{*}$ and $n-\pi^{*}$ transitions of carbonyl group of coumarin ring and the former was due to electronic transitions in the benzenoid system of three ethylenic bonds, which were in a closed cyclic conjugation known as E-band transitions. The absorption spectrum of PACON indicated the incorporation of the AgNPs ${ }^{68}$ where the presence of a Surface Plasmon Resonance (SPR) band at $\sim 410 \mathrm{~nm}$ was characteristic of $\mathrm{AgNPs}^{69}$ and the peak width at half maximum was $\sim 50 \mathrm{~nm}$. Absorption band for hexagonal AgNPs was observed at $410 \mathrm{~nm} \cdot{ }^{70}$ Formation of anisotropic particles ${ }^{71}$ has been indicated by the broadness and asymmetry of the UV-vis absorption curve, which

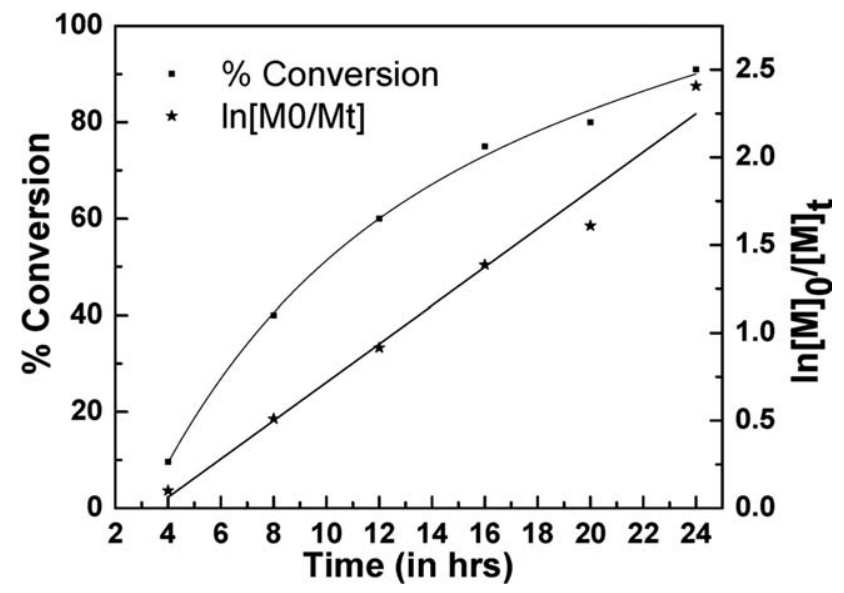

Figure 5 Kinetic plots of conversion (\%) vs. time for the polymerization of $\mathrm{ACO}$ in toluene at $110^{\circ} \mathrm{C}$, ([ACO] : [BIBB] : [CuBr] : [Bpy] $=40: 1: 1: 2)$. may be due to broad particle size distribution (PSD) and agglomeration of the Ag nanoparticles.

\section{Kinetics of living radical polymerization of ACO monomer}

The polymerization of ACO was undertaken in dry toluene to allow for solubilization of all the components (Scheme 1). Samples were withdrawn at different time intervals for the estimation of \% conversion through ${ }^{1} \mathrm{H}-\mathrm{NMR}$ [eq. (4)]. Average molecular weights $\left(M_{n}\right)$ and molar mass dispersion $\left(\bigoplus_{m}\right)$ were determined by ${ }^{1} \mathrm{H}-\mathrm{NMR}$ and GPC. Using BIBB as initiator, the polymerization of ACO gave a conversion of $\sim 40 \%$ in $8 \mathrm{~h}$. The conversion increased linearly with time up to $40 \%$ and it increased at a faster rate in the first $8 \mathrm{~h}$. If the number of active sites is constant over time, the reaction kinetics in ATRP is expected to follow a first-order behavior. The plot of $\ln \left([M]_{0} /[M]_{t}\right)$ vs. time exhibited pseudo first-order kinetics with respect to monomer with $\sim 3.15 \mathrm{~h}$ induction time but, showed deviation in the last $4 \mathrm{~h}$ of polymerization (Fig. 5). Monomer conversion increased linearly upto $40 \%$ in $8 \mathrm{~h}$, therefore, the first order rate was followed upto $40 \%$ conversion

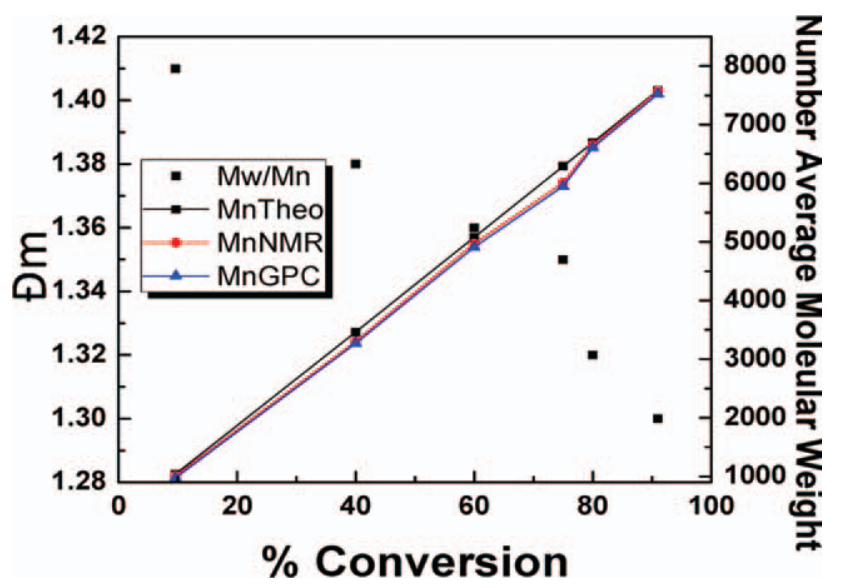

Figure 6 Combined plot for the evolution of $M_{n}$ and $\bigoplus_{m}$ vs. conversion (\%) for the polymerization of ACO in Toluene at $110^{\circ} \mathrm{C},([\mathrm{ACO}]:[\mathrm{BIBB}]:[\mathrm{CuBr}]:[\mathrm{Bpy}]=40: 1: 1$ : 2 ). [Color figure can be viewed in the online issue, which is available at wileyonlinelibrary.com.] 
TABLE I

Effect of Time on the Polymerization of 4-Allyloxy-chromen-2-one with $\mathrm{CuBr}$ and 2,2 $2^{\prime}$ Bypyridyl in Presence of BIBB at $110^{\circ} \mathrm{C}^{\mathrm{a}}$

\begin{tabular}{lccccccc}
\hline S. No. & Time $(\mathrm{h})$ & \% Conversion & $M_{n \text { (Theo) }}$ & $M_{n(\mathrm{NMR})}$ & $M_{n(\mathrm{GPC})}$ & $\mathrm{Ð}_{m}$ & $\mathrm{DP} n$ \\
\hline 1 & 4 & 10 & 1039 & 1010 & 976 & 1.41 & 3.84 \\
2 & 8 & 40 & 3463 & 3303 & 3271 & 1.38 & 16 \\
3 & 12 & 60 & 5079 & 4970 & 4910 & 1.36 & 24 \\
4 & 16 & 75 & 6291 & 6010 & 5950 & 1.35 & 30 \\
5 & 20 & 80 & 6695 & 6653 & 6610 & 1.32 & 32 \\
6 & 24 & 91 & 7584 & 7570 & 7526 & 1.30 & 36.4 \\
\hline
\end{tabular}

${ }^{\mathrm{a}}[\mathrm{ACO}]=2 \mathrm{mmol},[\mathrm{Cu}(\mathrm{I}) \mathrm{Br}]=0.05 \mathrm{mmol},[\mathrm{BIBB}]=0.05 \mathrm{mmol},[\mathrm{bpy}]=0.010 \mathrm{mmol}$, temperature $=110^{\circ} \mathrm{C}$, time $=24 \mathrm{~h}$, solvent $=$ toluene, initiator efficiency, $f=1.00$, apparent rate constant $\left(K_{\text {app}}\right)=0.109 \mathrm{~h}^{-1}$ (obtained from the slope of $\ln [\mathrm{M}]_{0} /[\mathrm{M}]_{\mathrm{t}}$ versus time $(t)$ (Fig. 4).

since the concentration of growing radicals remained constant during the polymerization process.

From Figure 6, a linear increase of $M_{n \text { (NMR) }}(1010$ 7570) with conversion (10-91\%) has been observed and the molar mass dispersion $\left(\bigoplus_{m}=1.41-1.30\right)$ remained low throughout the polymerization. The $M_{n(\mathrm{GPC})}$ and $M_{n(\mathrm{NMR})}$ were roughly comparable to $M_{n \text { theo }}$ calculated from the monomer/initiator molar ratio and the monomer conversion using eqs. (4)-(6). The good agreement in $M_{n}$ values from theoretical, ${ }^{1} \mathrm{H}-\mathrm{NMR}$ and GPC further confirmed the proposed polymer structure and the success of controlled polymerization (Table I). The linearity of the $M_{n(\mathrm{GPC})}$ and $M_{n \text { (NMR) }}$ vs. conversion plot and the low values of $\mathrm{Ð}_{m}$ revealed that the initiator was efficient and the polymerization was well-controlled. Molecular weight increased linearly with increase in conversion along with narrow molar mass dispersion $\left(\mathrm{Ð}_{m}=\right.$ 1.41-1.30), which indicated a well controlled ATRP behavior. The initiator efficiency was calculated using eq. (7). Due to the relatively high initiator efficiency, $M_{n \text { (Theo) }}$ values were higher than the $M_{n \text { (GPC) }}$ and $M_{n(\mathrm{NMR})}$ values. Molar concentration ratio of [ACO] : [BIBB] : [Cu (I) $\mathrm{Br}]:$ [bpy] used in the kinetic study was $40: 1: 1: 2$.

\section{Temperature optimization}

To find the optimum temperature for ATRP process, polymerization was carried out at various temperatures. Polymerization was not achieved below $100^{\circ} \mathrm{C}$ hence; the effect of temperature on polymerization has been studied above $100^{\circ} \mathrm{C}$, that is, 100,110 , and $120^{\circ} \mathrm{C}$. The $\%$ conversion increased from 80 to 99 with increase in temperature from 100 to $120^{\circ} \mathrm{C}$ (run 1-3, Supporting Information Table S3). $80 \%$ conversion was observed in $24 \mathrm{~h}$ with $1.37 \mathrm{D}_{m}$ at $100^{\circ} \mathrm{C}$ while in the same time, 91\% conversion with 1.30 $\mathrm{Ð}_{m}$ was observed at $110^{\circ} \mathrm{C}$ and $99 \%$ conversion with $1.44 \mathrm{Ð}_{m}$ was observed at $120^{\circ} \mathrm{C}$. Therefore, $110^{\circ} \mathrm{C}$ was found to be the optimum temperature for the ATRP of ACO.
As shown in Figure 7, a plot of $\ln K$ and $\ln (K / T)$ versus $1 / T$ produces a straight line. The temperature dependency of the apparent rate constant $\left(k_{\mathrm{ap}}\right)$, the magnitude of enthalpy of activation $\left(\Delta H^{\ddagger}\right)$ and entropy of activation $\left(\Delta S^{\ddagger}\right)$ as well as activation energy $\left(E_{a}\right)$ were determined by evaluation of the resulting straight Eyring correlations through the Eyring and Arrhenius plots for the logarithmic values of the rate constant vs. $1 / T$ [using eqs. (8)-(11)]. The reaction of polymerization showed negative Entropy of activation $\left(\Delta S^{\ddagger}=-320 \mathrm{~J} \mathrm{~mol}^{-1} \mathrm{~K}^{-1}\right)$, which allowed a greater flexibility of the activated complex. Due to less rigid structures at the transition state, $-\Delta S^{\ddagger}$ suggested that at transition state, the movement of reactants was highly restricted which support the progress of the reaction with time. The positive value of Gibbs Free energy of activation, $\Delta G^{\ddagger}$ (195.63 $\mathrm{kJ} \mathrm{mol}^{-1}$ ) indicates that the formation of the transition state is not necessarily spontaneous and may occur under specific conditions. The activation energy $E_{a}\left(76.26 \mathrm{~kJ} \mathrm{~mol}^{-1}\right)$ and $\Delta H^{\ddagger}\left(73.07 \mathrm{~kJ} \mathrm{~mol}^{-1}\right)$ were very close to each other proving the feasibility of the reaction.

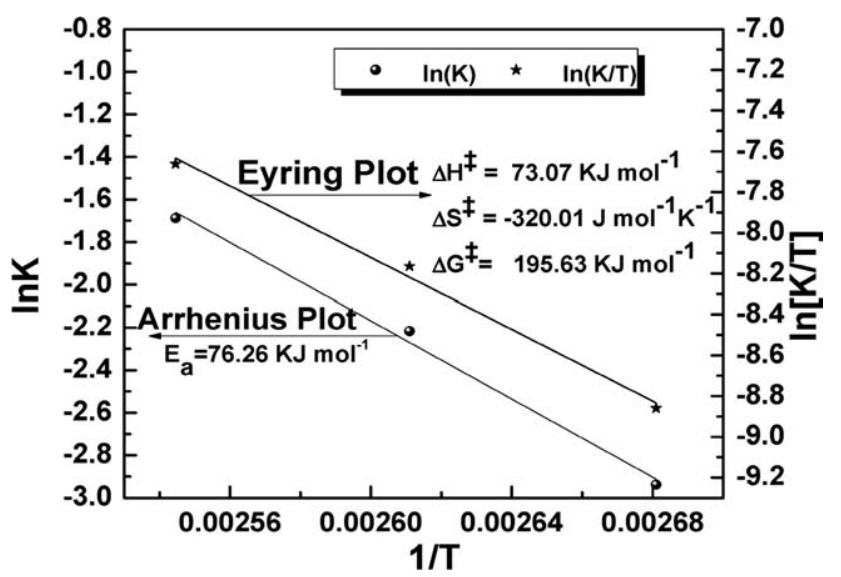

Figure 7 Arrhenius and Eyring plots of $\ln K$ and $\ln [K /$ T] vs. $1 / T$. 


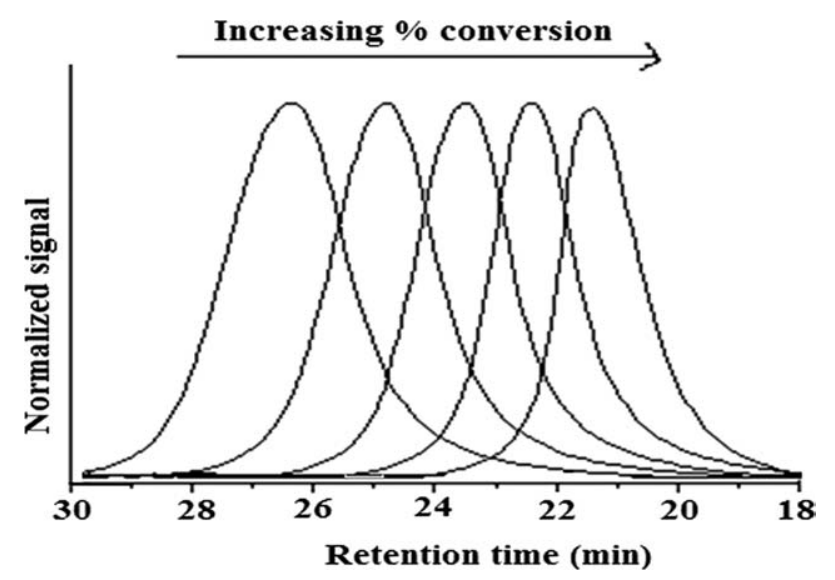

Figure 8 GPC traces of the ATRP polymerization of $\mathrm{PACO}$ with $\mathrm{BIBB}$ as initiator in Toluene at $110^{\circ} \mathrm{C}$. Molar ratio for polymerization $=[\mathrm{ACO}]:[\mathrm{BIBB}]:[\mathrm{CuBr}]:[\mathrm{Bpy}]$ $=40: 1: 1: 2$.

\section{GPC and chain extension analysis}

From Figure 8 , it has been observed that with increase in molecular weight, molar mass dispersion goes on decreasing gradually. To confirm further that the polymerization is a "living" progress, a chain extension experiment was carried out using obtained polymer as the macroinitiator (Fig. 9). The molecular weight increased with increase in conver-

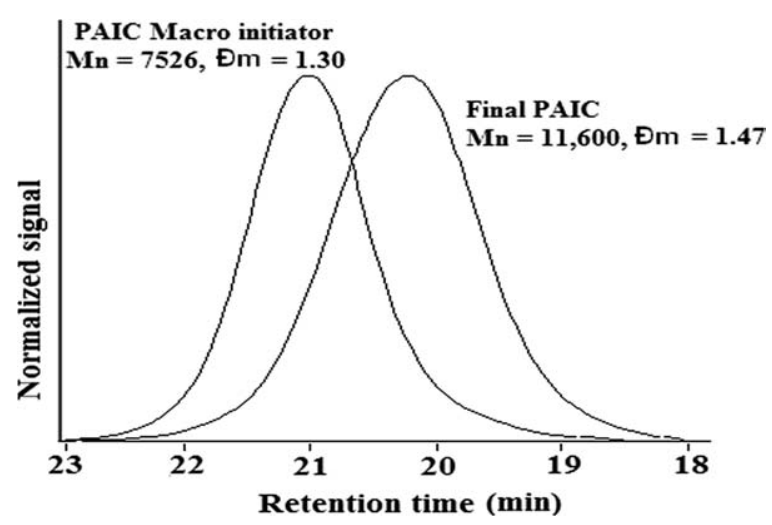

Figure 9 GPC traces of $\operatorname{PACO}\left(M_{n}=7526, \bigoplus_{m}=1.30\right)$ as macroinitiator and the successful chain extension with $\mathrm{ACO}$ as monomer.

sion whereas $\bigoplus_{m}$ also increased from 1.30 to 1.47 . The broadening of the GPC chromatogram may be due to increased $\bigoplus_{m}$ and high viscosity of the medium. This successful chain extension and characterization of polymer suggests that the polymerization is a living progress. The acceptable correlation of theoretical and experimental molecular masses, the linearity of the $M_{n}$ vs. conversion plots, the low $\bigoplus_{m}$ and the GPC separation of the macro initiator from the chain extended, demonstrated overall good control of molar mass dispersion during ATRP process
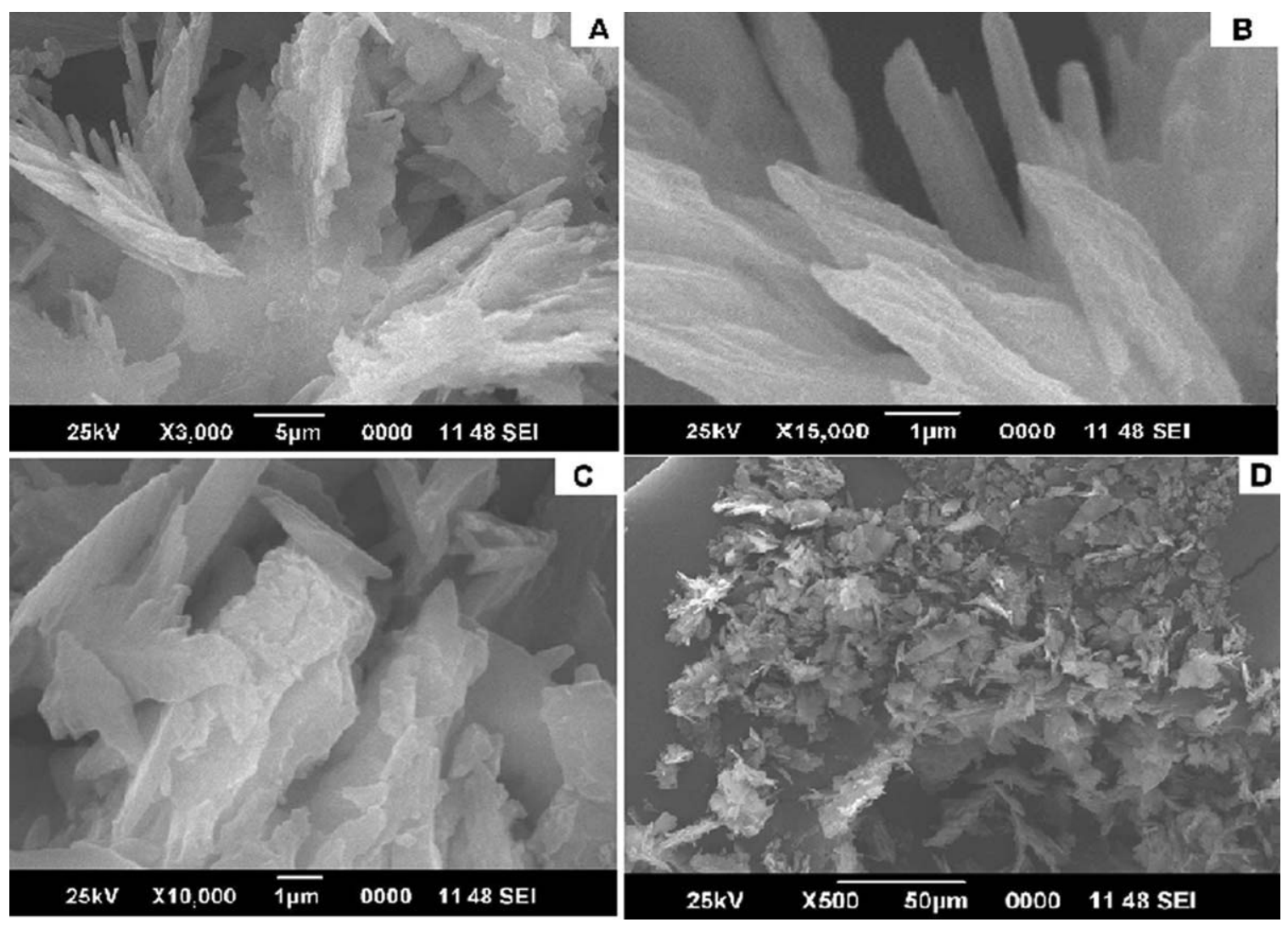

Figure 10 SEM images of the polymer (PACO). 


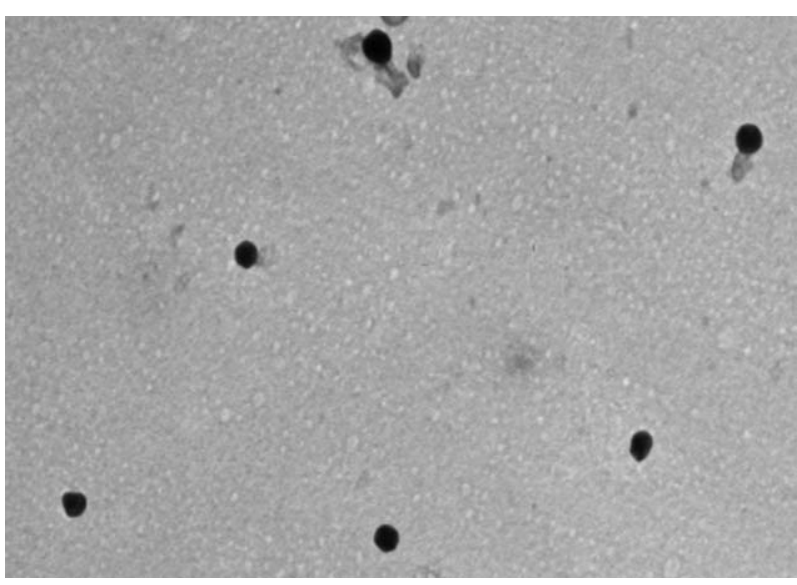

Figure 11 TEM image of the polymer nanocomposite.

of 4-allyloxy coumarin. All of the results indicate that the polymerization displayed the characteristics of a controlled process.

\section{SEM and TEM analysis}

Interestingly in the SEM micrograph [Fig. 10(a)], the polymer appeared like leaves extending out radically. Various rods like shapes have been observed in the Figure 10(b); In Figure 10(c), it appeared as if several nonuniform thin layers have been stacked over one another. The polymer surface was not smooth and it consisted of pointed rod like shapes with leaf like appearance. To fully exploit the properties of AgNPs, they should be well dispersed in the polymer host without the formation of large aggregates, which otherwise dramatically reduce the antimicrobial effect of silver. For the same reason, the size of the nanoparticles should be as small as possible with a narrow size distribution. The sufficiently high loading and free surface of nanoparticles are other important factors affecting the real applicability of polymeric Ag nanocomposites. Synthesis of AgNPs has been accomplished using silver nitrate as the $\mathrm{Ag}^{+}$ion source, which was reduced to metallic silver. Sodium borohydride was used as the reducing agent with borohydride anions assisting in stabilizing the formed Ag nanoparticles. The reduction of $\mathrm{Ag}^{+}$ion to $\mathrm{Ag}$ is evident from the appearance of yellow coloration. The yellow color results from the SPR band of Ag nanoparticles in the colloidal solution. AgNPs were incorporated in the polymer by a simple ultrasound-assisted method. ${ }^{72}$ Using water-THF mixture; a highly homogeneous distribution of nanosilver in PACO was achieved. The microjets formed as a result of sonochemical cavitation provided the incorporation of nanoparticles in the polymer. The incorporation of AgNPs in the polymer was characterized by TEM. Small drops of the nanocomposite dispersion were placed on

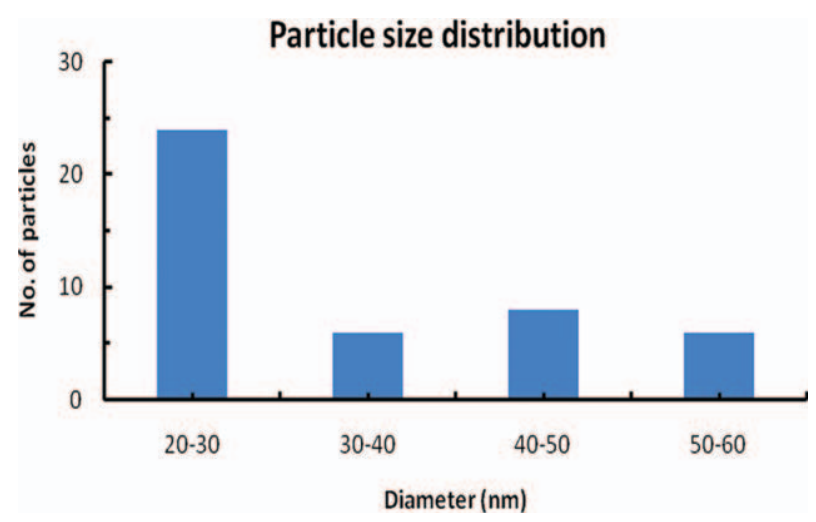

Figure 12 Histogram showing PSD of Ag nanoparticles. [Color figure can be viewed in the online issue, which is available at wileyonlinelibrary.com.]

copper grids coated with carbon film and dried in air. Figure 11 showed TEM image of the $\mathrm{PACO} / \mathrm{Ag}$ nanocomposite (PACON), which indicated the incorporation of the hexagonal nanoparticles well dispersed in the polymer matrix. The corresponding size distribution of Ag nanoparticles inside the polymer matrix indicated a broad distribution ranging from 28.90 to $53.80 \mathrm{~nm}$ of the AgNPs formed during the reaction. This range, called the PSD, has been represented in the form of a histogram (Fig. 12). Maximum of the height distribution was achieved at $28.77 \mathrm{~nm}$ and the rest was the extended "tail." A total number of about 44 particles were sampled to obtain a histogram of the size of the particle diameter. The average diameter of spherical nanoparticles was estimated to be $36.17 \mathrm{~nm}$.

\section{Thermal analysis}

In the thermal analysis, DSC and TGA/DTA studies were carried out for the polymer PACO. From the DSC curve (Fig. 13), it is clear that there is no

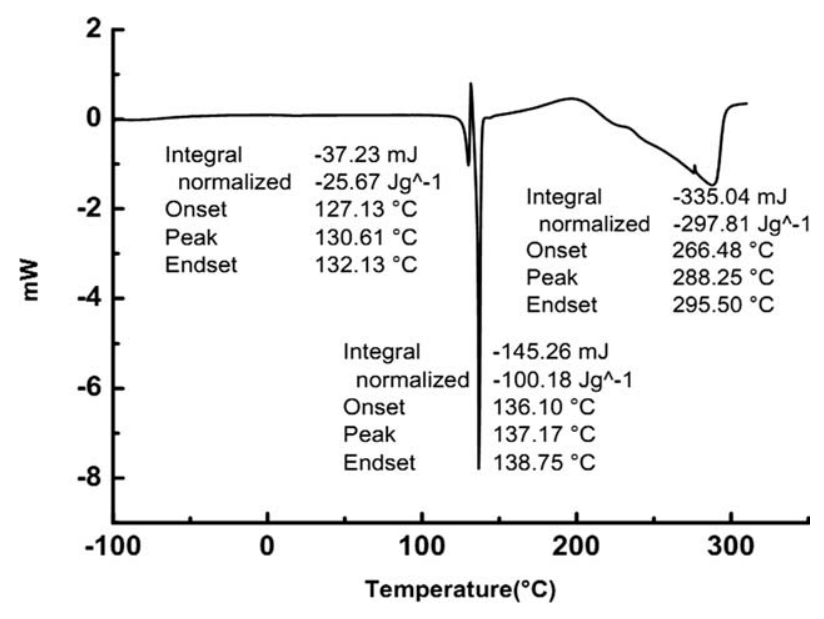

Figure 13 DSC curve of PACO. 


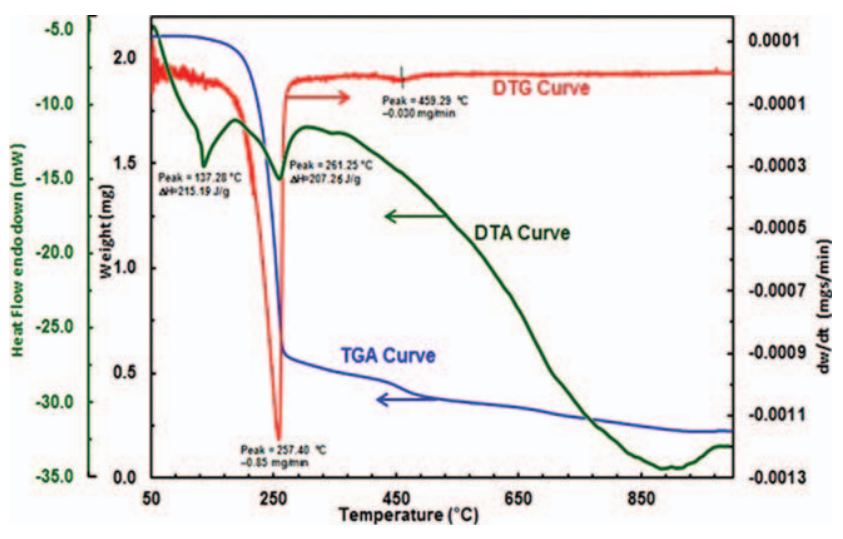

Figure 14 TGA/DTA and DTG curves of PACO. [Color figure can be viewed in the online issue, which is available at wileyonlinelibrary.com.]

exothermic peak. No $T_{g}$ was observed under the analysis conditions. It has also been observed that there are two melting point peaks occurring at 130 and $137^{\circ} \mathrm{C}$, respectively. The polymer showed a melting range of $127.13-132.13^{\circ} \mathrm{C}$ with a peak at $130.61^{\circ} \mathrm{C}$ and a heat of fusion of $-25.67 \mathrm{~J} \mathrm{~g}^{-1}$. Second range of melting was $136.10-138.75^{\circ} \mathrm{C}$ with a peak at $137.17^{\circ} \mathrm{C}$ and a heat of fusion of $-100.18 \mathrm{~J} \mathrm{~g}^{-1}$.

The rate of wt \% loss increased with increase of temperature upto $400^{\circ} \mathrm{C}$ (Fig. 14, Supporting Information Tables S4 and S5). After $400^{\circ} \mathrm{C}$, weight loss was gradual with maximum weight loss $(75 \%)$ in the range of 200 to $300^{\circ} \mathrm{C}$, was observed. The final degradation temperature (FDT) was $470^{\circ} \mathrm{C}$ and a char yield of $10 \%$ was obtained at $900^{\circ} \mathrm{C}$. The initial polymer decomposition temperature (initial PDT) and integral procedural decomposition temperature were 130 and $265.84^{\circ} \mathrm{C}$. Two $T_{\max }$ (i.e., the temperature at which maximum degradation occurs) were observed at 257 and $456^{\circ} \mathrm{C}$ (Supporting Information Table S6). From the TGA curve, a rapid weight loss has been observed in the temperature range of 200 $270^{\circ} \mathrm{C}$, as $70 \%$ of the polymer degraded in this range. This weight loss might be due to the elimination of the coumarin moiety, which existed as pendant in the polymer backbone and contributes almost $79 \%$ of the molecular weight of the polymer. Hence, major weight loss (almost 70\%) may be due to the elimination of the coumarin pendants from the polymer backbone. From 270 to $500^{\circ} \mathrm{C}, 12 \%$ weight loss occurred due to the elimination of carbonyl group from the residual part of the polymer. Same observa-
TABLE II Disc Diffusion Analysis

E. fecalis S. aureus E. coli P. mirabilis K. pneumonae

\begin{tabular}{llllll}
\hline $\mathrm{PACO}$ & ++ & - & - & - & - \\
$\mathrm{PACON}$ & +++ & - & - & - & - \\
\hline
\end{tabular}

Inhibition zone,$+<7 \mathrm{~mm} ;++, 8-15 \mathrm{~mm},+++,>15 \mathrm{~mm}$.

tions were obtained from the DTG curve (Fig. 14). A sharp peak at $257.40^{\circ} \mathrm{C}$ has been observed, which indicated $71.45 \%$ weight loss due to the elimination of the pendant coumarin moiety. In addition, a minor peak at $456.29^{\circ} \mathrm{C}$ was found due to carbonyl group elimination.

In the DTA curve (Fig. 14, Supporting Information Table S7), two endothermic peaks at 137.28 and $261.25^{\circ} \mathrm{C}$ were observed. $\Delta H$ corresponding to the peaks were found to be $215.19 \mathrm{~J} \mathrm{~g}^{-1}$ and $207.26 \mathrm{~J} \mathrm{~g}^{-1}$, respectively. The broad endothermic peak at $137.28^{\circ} \mathrm{C}$ was due to elimination of water present on surface of sample while the peak at $261.25^{\circ} \mathrm{C}$ was due to loss of coumarin moiety.

\section{Results of antibacterial studies}

Results obtained in this study by disc diffusion method showed that polymer/Ag nanocomposite inhibit the growth of $E$. fecalis more effectively than the polymer itself (Table II). MIC determination method also revealed the same results hence, the polymer (PACO) displayed moderate activity against E. fecalis with MIC value $50 \mu \mathrm{g} \mathrm{mL}^{-1}$ whereas its $\mathrm{Ag}$ nanocomposite was highly active with MIC value 32 $\mu \mathrm{g} \mathrm{mL}{ }^{-1}$ (Table III), due to the release of Ag nanoparticles which makes the polymer more attractive for biomedical applications ${ }^{73}$ and antibacterial coatings $^{74}$ due to its inherent antimicrobial properties. The polymer or its Ag nanocomposite showed no activity against the rest of the bacterial pathogens thus, PACO and its Ag nanocomposite are specifically active against $E$. fecalis.

\section{CONCLUSION}

A living polymer of 4-allyloxy-2H-chromen-2-one in toluene was synthesized by controlled radical polymerization method using ATRP protocol at $110^{\circ} \mathrm{C}$ with high conversion and good molecular weight control. The living nature of the polymer has been

TABLE III

MIC of Polymer and Its Ag Nanocomposite Against Five Bacterial Pathogens

\begin{tabular}{lccccc}
\hline & $\begin{array}{c}\text { E. fecalis } \\
\left(\mu \mathrm{g} \mathrm{mL}^{-1}\right)\end{array}$ & $\begin{array}{c}\text { S. aureus } \\
\left(\mu \mathrm{g} \mathrm{mL}^{-1}\right)\end{array}$ & $\begin{array}{c}\text { E. coli } \\
\left(\mu \mathrm{g} \mathrm{mL}^{-1}\right)\end{array}$ & $\begin{array}{c}\text { P. mirabilis } \\
\left(\mu \mathrm{g} \mathrm{mL}^{-1}\right)\end{array}$ & $\begin{array}{c}\text { K. pneumonae } \\
\left(\mu \mathrm{g} \mathrm{mL} \mathrm{mL}^{-1}\right)\end{array}$ \\
\hline PACO & 50 & - & - & - & - \\
PACON & 32 & - & - & - & - \\
\hline
\end{tabular}


proved by GPC and chain extension studies. Moreover thermal analysis of the polymer revealed that the initial polymer degradation temperature and FDT are $130^{\circ} \mathrm{C}$ and $470^{\circ} \mathrm{C}$ respectively. $E_{a}(76.26 \mathrm{~kJ}$ $\left.\mathrm{mol}^{-1}\right)$ and $\Delta H^{\ddagger}\left(73.07 \mathrm{~kJ} \mathrm{~mol}^{-1}\right)$ were very close to each other proving the feasibility of the reaction and negative value of entropy of activation $\left(\Delta S^{\ddagger}=\right.$ $-320 \mathrm{~J} \mathrm{~mol}^{-1} \mathrm{~K}^{-1}$ ) supported the highly restricted movement of reacting species at transition state. Surface analysis by SEM revealed that polymer had leaf-like structure. Antibacterial studies showed that the polymer is weakly active against Enterococcus fecalis with MIC value $50 \mu \mathrm{g} \mathrm{mL}^{-1}$ whereas its $\mathrm{Ag}$ nanocomposite shows high activity with MIC value $32 \mu \mathrm{g} \mathrm{mL}{ }^{-1}$ against Enterococcus fecalis.

Authors are thankful to Head, Department of Chemistry for providing laboratory facilities, NMR and IR spectra. Authors are thankful to SAIF, CUST Cochin for providing TGA/ DTG, DTA thermo grams, DSC analysis, SEM (EDAX) Micrograph. Authors also extend their thanks to Prof. R. N. Kharwar, Department of Botany, Faculty of Sciences, Banaras Hindu University, India, for the antibacterial analysis of the polymer and its Silver nanocomposites.

\section{References}

1. Stepto, R. F. T. IUPAC Pure Appl Chem 2009, 81, 351.

2. Hadjichristidis, N.; Pitsikalis, M.; Pispas, S.; Iatrou, H. Chem Rev 2001, 101, 3747.

3. Hawker, C. J.; Bosman, A. W.; Harth, E. Chem Rev 2001, 101, 3661.

4. Perrier, S.; Takolpuckdee, P.; Mars, C. R. Macromolecules 2005, 38, 2033.

5. Coessens, V.; Pintauer, T.; Matyjaszewski, K. Prog Polym Sci 2001, 26, 337.

6. Mishra, V.; Kumar, R. Carbohydr Polym 2011, 83, 1534.

7. Tsarevsky, N.; Sarbu, T.; Belt, B.; Matyjaszewski, K. Macromolecules 2002, 35, 6142.

8. Matyjaszewski, K.; Xia, J. Chem Rev 2001, 101, 2921.

9. Kamigaito, M.; Ando, T.; Sawamoto, M. Chem Rev 2001, 101, 3689.

10. Georges, M. K.; Veregin, R. P. N.; Kazmaier, P. M.; Hamer, G. K. Macromolecules 1993, 26, 2987.

11. Rodlert, M.; Harth, E.; Rees, I.; Hawker, C. J. J Polym Sci Part A: Polym Chem 2000, 38, 4749.

12. Moad, G.; Chiefary, J.; Chong, Y. K.; Krstina, J.; Mayadunne, R. T. A.; Postma, A. Polym Int 2000, 49, 993.

13. Wang, J. S.; Matyjaszewski, K. J Am Chem Soc 1995, 117, 5614.

14. Kato, M.; Kamigaito, M.; Sawamoto, M.; Higashimura, T. Macromolecules 1995, 28, 1721.

15. Percec, V.; Barboiu, B. Macromolecules 1995, 28, 7970.

16. Coessens, V.; Pintauer, T.; Matyjaszewski, K. Prog Polym Sci 2001, 26, 337.

17. Coessens, V.; Pyun, J.; Miller, P. J.; Gaynor, S. G.; Matyjaszewski, K. Macromol Rapid Commun 2000, 21, 103.

18. Wang, J. S.; Matyjaszewski, K. Macromolecules 1995, 28, 7572.

19. Xia, J. H.; Matyjaszewski, K. Macromolecules 1997, 30, 7692.

20. Zhu, S. M.; Wang, W. X.; Yan, D. Y. Acta Polym 1999, 50, 267.
21. Qin, D. Q.; Qin, S. H.; Qiu, K. J Polym Sci Part A: Polym Chem 2000, 38, 101.

22. Moineau, G.; Dubois, P.; Jerome, R. Macromolecules 1998, 31, 545.

23. Chen, X. P.; Qiu, K. Y. Macromolecules 1999, 32, 8711.

24. Qin, D. Q.; Qin, S. H.; Qiu, K. Y. Polymer 2000, 41, 7347.

25. Wang, W. X.; Dong, Z. H.; Zhang, Q. Macromol Rapid Commun 1998, 19, 647.

26. Parı's, R.; Fuente, J. L. Eur Polym J 2008, 44, 1403.

27. Sane, P. S.; Palaskar, D. V.; Wadgaonkar, P. P. Eur Polym J 2011, 47, 1621.

28. Mei, L. C.; Rui, B.; Jun, Q. J.; Fen, H.; Yan, X.; Chen, Z.; Yun, Z. Polym Bull 2006, 57, 139.

29. Patel, M. G.; Patel, H. J.; Patel, A. K.; Patel, K. H.; Patel, R. M. Malays Polym J 2011, 6, 70.

30. Patel, H. J.; Patel, M. G.; Patel, R. J.; Patel, K. H.; Patel, R. M. Ir Polym J 2008, 17, 635.

31. Chujo, Y.; Sada, K.; Saegusa T. Macromolecules 1990, 23, 2693.

32. Patel, H. J.; Patel, M. G.; Patel, A. K.; Patel, K. H.; Patel, R M. Express Polym Lett 2008, 2, 727.

33. Aziz, A. S. A.; Shipman, P. O.; Neeland, E. G.; Corkery, T. C.; Mohammed, S.; Harvey, P. D.; Mohamed, H. M.; Bedair, A. H.; Agrody, A. M.; Aguiar, P. M.; Kroeker, S. Macromol Chem Phys 2008, 209, 84.

34. Tian, Y.; Akiyama, E.; Nagase, Y.; Kanazawa, A.; Tsutsumi, O.; Ikeda, T. Macromol Chem Phys 2000, 201, 1640.

35. Trenor, S. R.; Schultz, A. R.; Love, B. J.; Long, T. E. Chem Rev 2004, 104, 3059.

36. Tanaka, K.; Fujiwara, T. Org Lett 2005, 7, 1501.

37. Schadt, M.; Seiberle, H.; Schuster, A. Nature 1996, 381, 212.

38. Obi, M.; Morino, S.; Ichimura, K. Chem Mater 1999, 11, 656.

39. Kim, C.; Trajkovska, A.; Wallace, J. U.; Chen, S. H. Macromolecules 2006, 39, 3817.

40. Lee, J.; Lee, J.; Sung, S.; Chu, H. Y.; Park, J.; Shim, H. Macromol Chem Phys 2004, 205, 2245.

41. Wang, B. Y.; Liu, X. Y.; Ding, S. L.; Su, Z. X. J Polym Res 2011, 18, 315.

42. Fomine, S.; Rivera, E.; Fomina, L.; Ortiz, A.; Ogawa, T. Polymer 1998, 39, 3551.

43. Chen, Y.; Hong, R. T. J Polym Sci Part A: Polym Chem 1997, 35, 2999.

44. Tlenkopatchev, M. A.; Fomine, S.; Fomina, L.; Gavino, R.; Ogawa, T. Polym J 1997, 29, 622.

45. Chen, Y.; Jean, C. S. J Appl Polym Sci 1997, 64, 1759.

46. Fomine, S.; Fomina, L.; Sanchez, C.; Ortiz, A.; Ogawa, T. Polym J 1997, 29, 49.

47. Chen, M.; Ghiggino, K. P.; Launikonis, A.; Mau, A. W. H.; Rizzardo, E.; Sasse, W. H. F.; Thang, S. H.; Wilsonb, G. J. J Mater Chem 2003, 13, 2696.

48. Kennedy, R. O'.; Thornes, R. D. Editors Coumarins; Wiley: Chichester, 1997.

49. Soine, T. O. J Pharm Sci 1964, 53, 231.

50. Pratibha, S.; Shreeya, P. Indian J Chem B 1999, 38, 1139.

51. Patonay, T. G.; Litkei, Y.; Bognar, R.; Erdei, J.; Misztic, C. Pharmazie 1984, 39, 86.

52. Shaker, R. M. Pharmazie 1996, 51, 148.

53. Manolov, I.; Danchev, N. D. Eur J Med Chem 1995, 30, 531.

54. Emmanuel-Giota, A. A.; Fylaktakidou, K. C.; HadjipavlouLitina, D. J.; Litinas, K. E.; Nicolaides, D. N. J. Heterocycl Chem 2001, 38, 717.

55. Nofal, Z. M.; El-Zahar, M.; Abd El-Karim, S. Molecules 2000, 5, 99.

56. Xie, L.; Tukeuchi, Y.; Consetino, L. M.; Lee, K. J Med Chem 1999, 42, 2662.

57. Burda, C.; Chen, X. B.; Narayanan, R.; El-Sayed, M. A. Chem Rev 2005, 105, 1025.

58. Keller, R. N.; Wycoff, H. D. Inorg Synth 1946, 2, 1. 
59. Perrin, D. D.; Armarego, W. L. F. Purification of laboratory chemicals. Oxford: Pergamon, 1988.

60. Park, S. J.; Cheol, L. J.; In, L. K. Bull Korean Chem Soc 2007, 1203.

61. Gond, S. K.; Mishra A.; Verma, V. K.; Verma, S. K.; Kumar, J.; Kharwar, R. N.; Kumar, A. Mycoscience, 2012, 53, 113; DOI 10.1007/s10267-011-0146-z.

62. Stalons, D. R.; Thornsberry, C. Antimicrob Agents Chemother 1975, 7, 15.

63. Sheldrick, G. M. Acta Crystallogr Sect A 2008, 64, 112.

64. Bruno, I. J.; Cole, J. C.; Edgington, P. R.; Kessler, M.; Macrae, C. F.; McCabe, P.; Pearson, J.; Taylor, R. Acta Crystallogr Sect B 2002, 58, 389.

65. Brandenburg, K.; Putz, H. Diamond version 3.0.; University of Bonn: Germany, 2004.

66. Farrugia, L. J Appl Crystallogr 1997, 30, 565.
67. Silverstein, R. M.; Webster, F. X., Eds. Spectrometric Identification of Organic Compounds, 6th ed.; Wiley: New York, 1998.

68. Kelly, K. L.; Coronado, E.; Zhao, L. L.; Schatz, G. C. J Phys Chem B 2003, 107, 668.

69. Li, T.; Park, H. G.; Choi, S. Mater Chem Phys 2007, 105, 325.

70. Sun, Y.; Xia, Y. Analyst 2003, 128, 686.

71. Jensen, T.; Kelly, L.; Lazarides, A.; Schatz, G. C. J. Cluster Sci 1999, 10, 295.

72. Perkas, N.; Shuster, M.; Amirian, G.; Koltypin, Y.; Gedanken, A. J Polym Sci Part A: Polym Chem 2008, 46, 1719.

73. Slawson, R. M.; Vandyke, M. I.; Lee, H.; Trevors, J. T. Plasmid 1992, 27, 72.

74. Kumar, A.; Vemula, P. K.; Ajayan, P. M.; John, G. Nat Mater $2008,7,236$ 